\title{
Hepatitis c, delta and human immunodeficiency virus sero-prevalence in patients chronically infected with hepatitis b virus in Cotonou, Benin
}

\begin{abstract}
Infections with hepatitis viruses are known to be prevalent in sub-Saharan Africa but in Benin, data on these infections are still scarce. The study was carried out to assess the burden of these infections in Cotonou. From June to October 2016, we conducted a cross-sectional study on 156 Hepatitis B Virus (HBV) infected patients attending the University Teaching Hospital and a private hospital in Cotonou. For each patient, HBV viral load measurement and Hepatitis Delta Virus (HDV), Hepatitis C Virus (HCV) and Human Immunodeficiency Virus (HIV) serology tests were performed using standard methods. The median HBV viral load was $557.5 \mathrm{UI} / \mathrm{mL}$ and HDV, HIV and HCV sero-prevalence rates were $3.9 \%, 1.3 \%$ and $0.7 \%$ respectively. In conclusion, in $\mathrm{HBV}$ infected patients in Cotonou, the sero-prevalence rates of HDV, HCV and HIV were relatively low. A national prevalence survey is needed to assess the epidemiology of these infections in the country.
\end{abstract}

Keywords: HBV, HCV, HDV, HIV, Cotonou
Volume 5 Issue 5 - 2017

\author{
Dissou Affolabi, ${ }^{1,2}$ Raimi Kpossou, ${ }^{1,2}$ Frederic \\ Sogbo, ${ }^{1,2}$ Alexandra Zomahoun,' Desiree \\ Metodakou, ${ }^{2}$ Barnabe Lafia, ${ }^{2}$ Aboudou Chabi \\ Do,' Jeanne Orekan, ${ }^{1,2}$ Faridath Massou, ${ }^{\prime}$ \\ Aderemi Kehinde ${ }^{3,4}$ \\ 'Faculty of Health Sciences, Abomey-Calavi University, Nigeria \\ ${ }^{2}$ National Teaching Hospital Hubert Koutoukou Maga, Nigeria \\ ${ }^{3}$ Department of Medical Microbiology \& Parasitology, College of \\ Medicine, University of Ibadan, Nigeria \\ ${ }^{4}$ Department of Medical Microbiology \& Parasitology, University \\ College Hospital, Nigeria
}

Correspondence: Dissou Affolabi, Faculty of Health Sciences, Abomey-Calavi University, National Teaching Hospital Hubert Koutoukou Maga, Cotonou, Benin, OI BP I 88 Nigeria, Tel 22966 6I 48 62,Email affolabi_dissou@yahoo.fr

Received: May 28, 2017 | Published: July 10, 2017
Abbreviations: CI, Confidence Interval; EDTA, Ethylene Diamine Tetra Acetic Acid; HBV, Hepatitis B Virus; HCV, Hepatitis C Virus; HDV, Hepatitis Delta Virus; HIV, Human Immunodeficiency Virus; WHO, World Health Organization

\section{Introduction}

According to the World Health Organization (WHO), about 257 million people live with Hepatitis B virus (HBV) worldwide SubSaharan Africa represents an area of high prevalence of this infection with more than $8 \%$ of chronic carriers. ${ }^{1}$ In addition, HBV-infection is a major cause of deaths in this region due to complications such as cirrhosis and hepatocellular carcinoma. ${ }^{1}$ Hepatitis delta virus (HDV) is a defective virus that depends on the HBV surface antigen (HBsAg) for its existence. Therefore, infection with HDV requires necessarily HBV infection, either simultaneous infection with both viruses or HDV infection in a subject previously infected with HBV. Compared with infection with HBV alone, HDV infection leads to more rapid progression of liver disease to cirrhosis and hepatocellular carcinoma. ${ }^{2-4}$ The number of people infected with HDV is estimated at 15 to 20 million worldwide. ${ }^{5}$ In spite of this information, there is scarcity of data on the disease estimate in many endemic areas particularly in sub-Saharan Africa. HBV and HDV share with the hepatitis $\mathrm{C}$ virus (HCV) and human immunodeficiency virus (HIV) the same blood transmission route. In addition, co-infection with HIV and/or HCV worsens the liver disease in HBV and/or HDV infected patients. Data on HCV infection is rare in sub-Saharan Africa but a review from Riou et al. ${ }^{6}$ ranged the prevalence in this region from $0.0 \%$ to $56.0 \%{ }^{6}$ Since HIV infection is endemic in Africa region, the occurrence of HIV co-infection with hepatitis viruses may also be on a high side. In Benin, data on co-infection with HDV, HCV and HIV in HBV infected patients are rare. To our knowledge, the only two published studies on co-infection with these viruses were on a limited number of patients in one hospital in the Northern part of the country. ${ }^{7,8}$ We aimed in the present study to assess the prevalence of $\mathrm{HDV}, \mathrm{HCV}$ and HIV infections in patients chronically infected with HBV in Cotonou, the largest city in Benin.

\section{Materials and methods}

\section{Setting}

Benin is a country with a size of 114,763 square kilometers and an estimated population of 10.9 million. ${ }^{9}$ Cotonou is the biggest city in the country with approximately 673,000 populations in $2013 .{ }^{10}$

\section{Subjects}

This cross-sectional study was conducted from June to October 2016 in two hospitals in Cotonou: the university teaching hospital, Hubert Koutoukou Maga, which is a public hospital and the Atinkanmey polyclinic, the biggest private hospital in the city. In total, 156 subjects (15 years and above) chronically infected with HBV and attending these hospitals during the study period were consecutively included in the study. These subjects were previously detected positive with HBs antigen and followed up in these hospitals. None of them was under treatment for HBV infection.

\section{Sample}

Venous blood was collected from each subject into two tubes. Ethylene diamine tetra acetic acid (EDTA) tubes were used to collect blood for plasma separation (viral load measurement) while plain tubes were used for serum separation (serology). All tests were performed and interpreted according to manufacturer's instructions. Anti-HDV antibody was detected using ETI-AB-DELTAK-2 ${ }^{\circledR}$ kit (Diasorin, France) while in positive samples, anti-HDV IgM were detected with ETI-AB-DELTA-IGMK-2® kit (Diasorin, France). 
$\mathrm{HCV}$ testing was performed using immuno chemiluminescence antiHCV ${ }^{\circledR}$ II test (Roche Diagnostics, USA) or VIDAS Anti-HCV® Assay (bio Merieux, France). HIV serology was performed using Alere Determine HIV-1/2 ${ }^{\circledR}$ test (Alere Medical, Japan) for screening while samples that were reactive were confirmed by Immuno Comb HIV 1\&2 BiSpot ${ }^{\circledR}$ (Orgenics, France). HBV viral load measurement was carried out using Cobas TaqMan ${ }^{\circledR} 48$ kit (Roche Diagnostics, USA).

\section{Ethical considerations}

All patients gave informed consents and the study was approved by the institutional review board.

\section{Data analysis}

Data were collected using Epi Data version 3.1 and statistical analyses were performed using Stata software version 12.0.

\section{Results}

In total, $156 \mathrm{HBV}$ infected patients were included in the study. Their characteristics are presented in (Table 1). Median age of patients was 36.0 years with a male to female ratio of 2.0:1.0. The median HBV viral load was $557.5 \mathrm{UI} / \mathrm{mL}$ while in two thirds of the patients (67.3\%), the HBV viral load was less than 2,000 UI/mL; among them, three had undetectable HBV viral load (Table 1). Of the $156 \mathrm{HBV}$ infected patients, six $(3.9 \%)$ were screened positive for anti-HDV antibodies of which, two (33.3\%) were positive for anti-HDV IgM antibodies. In HBV infected patients, HIV and HCV sero-prevalence rates were $1.3 \%, 95 \% \mathrm{CI}=0.5 \%-3.1 \%$ and $0.7 \%, 95 \% \mathrm{CI}=0.6 \%$ $2.0 \%$ respectively (Table 2 ). No HBV infected patient was co-infected with the other three viruses.

Table I Characteristics of patients included in the study

\begin{tabular}{lll}
\hline $\begin{array}{l}\text { Patients } \\
\text { Number }\end{array}$ & & Persantage \\
\hline $\begin{array}{ll}\text { Gender } \\
\text { Male }\end{array}$ & 104 & 66.7 \\
Female & 52 & 33.3 \\
Age (years) & & \\
I5-24 & 21 & 13.5 \\
$25-34$ & 46 & 29.5 \\
$35-44$ & 49 & 31.4 \\
$45-54$ & 23 & 14.7 \\
$\geq 55$ & 17 & 10.9 \\
HBV viral load (UI/mL) & & \\
$<2,000$ & 105 & 67.3 \\
$\geq 2,000$ & 51 & 32.7 \\
\hline
\end{tabular}

Table 2 Results of HCV, HDV and HIV serology

\begin{tabular}{lll}
\hline $\begin{array}{lll}\text { Patients } \\
\text { Number }\end{array}$ & & Persantage \\
\hline HCV & & \\
Positive & 2 & 1.3 \\
Negative & 149 & 98.7 \\
HDV & & \\
Positive & 6 & 3.9 \\
Negative & I50 & 96.1 \\
HIV & & \\
Positive & I & 0.7 \\
Negative & 147 & 99.3 \\
\hline
\end{tabular}

\section{Discussion}

Information on HDV infection is rare in Africa. However, the magnitude of the problem needs to be assessed in a particular setting in order to set up appropriate measures to tackle the disease. In this study, the sero-prevalence of anti-HDV antibody was 3.9\%. This finding was in agreement with 3.0\% and 3.2\% found in Senegal and Uganda respectively. ${ }^{11}$ However, it is of worthy to note that in the two previous studies, HIV\& HBV co-infected patients were exclusively reported while only two HIV\&HBV co-infected patients were found in the present study. In other studies elsewhere in Africa, prevalence varied from $0-50 \%$ was reported without any clear explanation on these variations. ${ }^{12-14}$ In two previous studies carried out in the northern part of Benin, Zanchetta et al. $^{7}$ reported $19.4 \%$ prevalence rate for anti-HDV antibodies while a rate of $11.4 \%$ was reported by de Paschale et al. some years later. ${ }^{8}$ These findings were higher than what was found in the present study. Ndumbe et al. ${ }^{16}$ reported that in a given country, HDV sero-prevalence might vary from one region to another. ${ }^{15,16}$ These variations may be due to geographical and cultural differences such as non-medical circumcision and scarification within a country. These differences in fact may be the explanations why some regions are more susceptible to HDV transmission than the other regions. To this end, a national prevalence survey is advocated to have the actual picture of this infection in the country. Out of the six patients with anti-HDV antibodies, anti-HDV IgM was positive in two $(33.3 \%)$. Only these two patients were theoretically considered of having an active HDV infection. However, one cannot exclude active HDV infection in patients with negative anti-HDV IgM since a more sensitive test (HDV PCR) was not performed. This is the main limitation of this study. In our study, HIV sero-prevalence was $0.7 \%$ similar to what was observed in the general population $(1.1 \%) .{ }^{17}$

Several studies in sub-Saharan Africa had investigated HBV infection in HIV infected patients and showed a higher co-infection rates of $16.8 \%, 13.6 \%$ and $11.1 \%$ in Senegal, Ghana and Benin respectively. ${ }^{18,19}$ This observation showed that the risk of HBV infected patients to be infected with HIV was lower than that of HIV infected patients to be infected with HBV. Possible explanations for this are the fact that most HBV infected patients in our setting are infected during infancy and their characteristics regarding HIV infection are similar to those of the general population. In contrary however, HIV infected patients represent a specific group with an increased risk of sexual transmission for both HIV and HBV. HCV sero-prevalence was $1.3 \%$ in our study. Previous studies within the country showed a prevalence ranging from $0.7 \%$ in Cotonou to $7.4 \%$ in pregnant women in Tanguieta. ${ }^{8,}{ }^{20}$ In other countries in Africa, reports showed that $\mathrm{HCV}$ prevalence were generally relatively low. ${ }^{6}$ This is fortunate since both viruses cause liver damages leading to cirrhosis and hepatocellular carcinoma. Common effects of both viruses may accelerate progression to these complications. In contrast to HIV/ AIDS, there are no national programs to address policies on viral hepatitis in most sub-Saharan Africa countries including Benin despite the high prevalence of these infections in the region. ${ }^{1,5,6,17}$ As a result, epidemiological data available on hepatitis infections are either scarce or not representative of the population of patients infected. The present study contributes in getting a picture of the situation and may help in setting up measures to fight against these viruses..$^{21,22}$

\section{Conclusion}

In HBV infected patients in Cotonou, sero-prevalence rates of HDV, $\mathrm{HIV}$ and $\mathrm{HCV}$ infections were $3.9 \%, 1.3 \%$ and $0.7 \%$ respectively. These rates seem lower than what was previously reported in the northern part of the country. A national prevalence survey is urgently needed to determine the actual picture of the epidemiology of these infections in the country. 


\section{Acknowledgments}

None.

\section{Conflicts of interest}

Authors declare no conflict of interest.

\section{References}

1. Hepatitis B fact sheet, WHO. 2017.

2. Flores R, Ruiz-Ruiz S, Serra P. Viroids and hepatitis delta virus. Semin Liver Dis. 2012;32(3):201-210.

3. Wedemeyer H, Manns MP. Epidemiology, pathogenesis and management of hepatitis D: update and challenges ahead. Nat Rev Gastroenterol Hepatol. 2010;7(1):31- 40.

4. Pascarella S, Negro F. Hepatitis D virus: An update. Liver Int. 2011;31(1):7-21.

5. Hepatitis D fact sheet, WHO. 2017.

6. Riou J, Aït Ahmed M, Blake A, et al. Hepatitis C virus seroprevalence in adults in Africa: a systematic review and meta-analysis. HCV epidemiology in Africa group. $J$ Viral Hepat. 2016;23(4):244-255.

7. Zanchetta N, Vigano P, Ferrario MP, et al. B and delta hepatitis virus infection in a population of west Africa. Rev Inst Med Trop Sao Paulo. 1990;32(1):36-40.

8. De Paschale M, Ceriani C, Cerulli T, et al. Prevalence of HBV, HDV, $\mathrm{HCV}$, and HIV infection during pregnancy in northern Benin. $J$ Med Virol. 2014;86(8):1281-1287.

9. UNDP, Human Development Report. 2017.

10. INSAE Benin. Benin, portail de données.

11. Diop-Ndiaye H, Touré-Kane C, Etard JF, et al. Hepatitis B, C Seroprevalence and Delta Viruses in HIV-1 Senegalese Patients at HAART Initiation (Retrospective Study) $J$ Med Virol. 2008;80:1332-1336.
12. Katwesigye E, Seremba E, Semitala F, et al. Low sero-prevalence of hepatitis delta antibodies in HIV/ hepatitis B co-infected patients attending an urban HIV clinic in Uganda. Afr Health Sci. 2016;16(4):1089-1093.

13. Bekondi $\mathrm{C}$, Mobima T, Ouavènè JO, et al. Etiopathological factors of hepatocellular carcinoma in Bangui, Central African Republic: clinical, biological characteristics and virological aspects of patients. Pathol Biol (Paris). 2010;58(2):152-155.

14. Lunel-Fabiani F, Mansour W, Amar AO, et al. Impact of hepatitis B and delta virus co-infection on liver disease in Mauritania: A cross sectional study. J Infect. 2013;67(5):448-457.

15. Cunha L, Plouzeau C, Ingrand P, et al. Use of replacement blood donors to study the epidemiology of major blood-borne viruses in the general population of Maputo, Mozambique. J Med Virol. 2007;79(12):1832-1840.

16. Ndumbe P. Hepatitis D in Yaounde, Cameroon APMIS. 1991;99(1-6):196-198.

17. Poveda JD, Delord B, Chancerel B, et al. Carriage of HBs antigen and infection by delta agent in Cameroon. Bull Soc Pathol Exot Filiales. 1986;79(5 Pt 2):785-787.

18. WHO. Prevalence of HIV among adults aged 15 to 49Estimates by country (2000-2014), WHO. 2017

19. Agyeman AA, Ofori-Asenso R. Prevalence of HIV and hepatitis B coinfection in Ghana: a systematic review and meta-analysis. AIDS Res Ther. 2016;13:1-23.

20. Affolabi D, Ade G, Faïhun F, et al. Double infection with HIV and HBV among patients with tuberculosis in Cotonou. Journal de la Société Béninoise de Biologie Clinique. 2012;16:29-33.

21. Develoux M, Boni G, Aguessy Ahyi B, et al. The prevalence of antihepatitis $\mathrm{C}$ antibodies in pregnant women and blood donors in Benin Bull Soc Pathol Exot. 1995;88(3):115-116. 